\title{
IMPLEMENTASI PROGRAM SERTIFIKASI GURU DALAM JABATAN (STUDI PADA MADRASAH ALIYAH NEGERI CIPARAY KABUPATEN BANDUNG)
}

\section{THE IMPLEMENTATION OF TEACHER CERTIFICATION PROGRAM (STUDIES IN MADRASAH ALIYAH NEGERI CIPARAY DISTRICT BANDUNG)}

\author{
Ningrum Fauziah Yusuf; Herijanto Bekti; Dedi Sukarno \\ ningrumfy@gmail.com; herijanto.bekti@unpad.ac.id; dedi.sukarno@unpad.ac.id \\ Program Studi Administrasi Publik \\ Fakultas Ilmu Sosial dan Ilmu Politik \\ Universitas Padjadjaran \\ Bandung, Indonesia
}

\begin{abstract}
ABSTRAK
Menyadari akan pentingnya peranan pendidikan dalam meningkatkan kualitas sumber daya manusia, pemerintah berupaya untuk meningkatkan kualitas guru melaksanakan sebuah program sertifikasi guru. Tujuan penelitian ini ialah untuk mengetahui bagaimana proses implementasi program sertifikasi guru untuk guru madrasah yang dilakukan oleh Kementerian Agama Kabupaten Bandung. Teori yang digunakan dalam penelitian ini adalah teori implementasi program menurut Charles O. Jones yang menyebutkan tiga aktivitas dasar yaitu organisasi, interpretasi, dan aplikasi. Metode penelitian yang digunakan adalah kualitatif deskriptif dengan teknik penentuan informan menggunakan teknik purposive. Hasil penelitian menunjukan bahwa implementasi program sertifikasi guru dalam jabatan khususnya pada guru Madrasah Aliyah Negeri Ciparay yang dilakukan oleh Kementerian Agama Kabupaten Bandung pada pelaksanaannya belum optimal karena masih terdapat beberapa kendala yang dihadapi. Dilihat dari organisasi masih kurangnya sumber daya manusia dan sumber daya finansial yang tersedia. Dari aspek interpretasi, para pelaksana program sudah memahami tujuan dan pedoman program akan tetapi dalam pelaksanaan tugas dan fungsinya masih belum konsisten. Dalam aspek aplikasi, ditemukan pengawasan pada pelaksanaan program tidak berjalan, terlihat pada belum adanya laporan evaluasi untuk pelaksanaan program sertifikasi guru dalam jabatan yang telah dilaksanakan pada tahun-tahun sebelumnya.
\end{abstract}

Kata Kunci: Implementasi Program, Sertifikasi Guru, Profesionalisme Guru

\section{ABSTRACT}

Recognizing the importance of the role of education in improving the quality of human resources, the government seeks to improve the quality of teachers to implement a teacher certification program. The purpose of this study was to find out how the process of implementation of the teacher certification program for madrasah teachers conducted by Kementerian Agama District Bandung. The theory used in this research is the theory of program implementation by Charles O. Jones who cites three basic activities, namely the organization, interpretation, and application. The method used is descriptive qualitative determination techniques informants usingtechnique. purposive sampling. The results showed that the implementation of certification of teachers, especially teachers of Madrasah Aliyah Negeri Ciparay conducted by Kementerian Agama District Bandung not optimal because there are still some obstacles encountered. Judging from organizations still lack the human resources and financial resources available. From the aspect of interpretation, all program managers have understood the objectives and guidelines for the program but in the implementation of tasks and functions are still not consistent. In the 
aspect of the application, found the supervision of the implementation of the program is not running, is seen in the absence of an evaluation report on the implementation of in-service teacher certification program that has been implemented in previous years

\section{Keywords: Implementation Program, Teacher Certification, Teacher Professionalism}

\section{PENDAHULUAN}

Kualitas sumber daya manusia yang dihasilkan dari pembangunan pendidikan saat ini masih menunjukkan bahwa daya saing bangsa Indonesia di dunia Internasional masih relatif rendah. Menurut hasil laporan penelitian United Nation Development Programme (UNDP) pada tahun 2015 tentang Indeks Pembangunan Manusia menyatakan Indonesia berada pada peringkat ke-110 dari 187 negara dengan nilai IPM mencapai 0,684.

Menyadari akan pentingnya peranan pendidikan dalam meningkatkan kualitas sumber daya manusia, pemerintah berupaya untuk meningkatkan kualitas guru dengan mengeluarkan sebuah kebijakan tentang Sertifikasi Guru dan Dosen. Karena salah satu penyebab rendahnya mutu pendidikan di Indonesia adalah komponen mutu guru.

Program sertifikasi guru merupakan rangkaian kegiatan pelaksanaan keputusan pemerintah pusat yang diberikan kewenangan kepada pemerintah daerah dalam peningkatan mutu pendidikan, maka keberhasilan program sangat tergantung pada pemahaman, kesadaran, keterlibatan dan upaya sungguh-sungguh dari segenap aktor pelaksana program. Program sertifikasi guru ini merupakan proses yang berkelanjutan, monitoring dan evaluasi pun harus terus dilakukan secara berkala terhadap guru yang telah mendapatkan sertifikat untuk memantau kinerja guru setelah mendapatkan sertifikat pendidik. Program sertifikasi guru, bagi peneliti adalah sesuatu hal yang menarik untuk diteliti karena merupakan bagian penting dari peningkatan kualitas pendidikan di Indonesia melalui peningkatan mutu dan kesejahteraan guru, khususnya di Kabupaten Bandung.

Program sertifikasi guru dalam jabatan ini lahir berdasarkan UndangUndang Sisdiknas No. 20 Tahun 2003 tentang sistem pendidikan Nasional, dan Undang-Undang Nomor 14 Tahun 2005 Tentang Guru dan Dosen, serta Peraturan Pemerintah Nomor 74 Tahun 2008 tentang Guru yang mengamanatkan, di mana guru wajib memiliki kualifikasi akademik, kompetensi, dan sertifikat pendidik.

Madrasah Aliyah Negeri yang merupakan salah satu lembaga pendidikan formal pada jenjang menengah dibawah naungan Kementerian Agama Kabupaten Bandung, yang diselenggarakan untuk melanjutkan dan meluaskan pendidikan dasar serta menyiapkan peserta didik menjadi anggota masyarakat yang memiliki kemampuan mengadakan hubungan timbal balik dengan lingkungan sosial, budaya, dan alam sekitar serta dapat mengembangkan kemampuan lebih lanjut dalam dunia kerja atau pendidikan tinggi.

Berdasarkan survei awal yang telah peneliti lakukan di Madrasah Aliyah Negeri Ciparay Kabupaten Bandung diperoleh hasil bahwa ternyata kualitas proses pembelajaran yang dilakukan guru didalam kelas belum berjalan secara optimal atau belum memperlihatkan peningkatan secara signifikan padahal para guru tersebut sudah sertifikasi. Berikut data jumlah guru dan guru yang menerima sertifikasi di MAN Ciparay Kabupaten Bandung adalah sebagai berikut: 
Tabel 1.1 Guru Penerima Tunjangan Profesional atau Dana Sertifikasi Pada Madrasah Aliyah Negeri Ciparay Kabupaten Bandung Tahun 2016

\begin{tabular}{|c|c|}
\hline \multicolumn{2}{|c|}{$\begin{array}{l}\text { Madrasah Aliyah Negeri Ciparay } \\
\text { Kabupaten Bandung }\end{array}$} \\
\hline Jumlah Guru PNS & 42 \\
\hline Jumlah Guru Non-PNS & 13 \\
\hline $\begin{array}{l}\text { Jumlah Guru Penerima } \\
\text { Sertifikasi atau TPG }\end{array}$ & 41 \\
\hline Jumlah Siswa & 597 \\
\hline
\end{tabular}

(Sumber: MAN Ciparay, 2016)

Dapat kita lihat dari tabel 1.1 bahwa $75 \%$ dari guru yang mengajar di Madrasah Aliyah Negeri Ciparay Kabupaten Bandung sudah mempunyai sertifikat pendidik atau dengan kata lain guru tersebut sudah sertifikasi. Sudah menjadi sebuah kewajiban para guru yang sudah mempunyai sertifikat pendidik bisa menjadi tenaga profesional.

Banyaknya jumlah guru yang menerima sertifikasi di Madrasah Aliyah Negeri Ciparay Kabupaten Bandung menjadi daya tarik bagi penulis. Dengan banyaknya jumlah guru yang menerima sertifikasi di Madrasah Aliyah Negeri Ciparay Kabupaten Bandung maka sudah seharusnya mutu pendidikan dan profesionalitas guru dalam hal mengajar menjadi semakin membaik.

Mengingat karakteristik dan kondisi guru Madrasah serta struktur organisasi dan kelembagaan Kementerian Agama, Direktorat Jenderal Pendidikan Islam melakukan adaptasi terhadap pedoman sertifikasi guru dari Kementerian Pendidikan dan Kebudayaan untuk dapat diterapkan dengan sebaik-baiknya.

Tujuan program sertifikasi guru akan tercapai dengan baik jika pelaksana maupun peserta dapat memahami dan mengerti maksud dari program ini serta mereka mempunyai kemampuan untuk melakukan tugas-tugas guna mencapai tujuan tersebut. Selain pemahaman akan tujuan, kemampuan guru dalam melaksanakan tugas-tugasnya dalam proses belajar mengajar merupakan poin penting yang harus selalu ditingkatkan.

Berdasarkan hasil observasi awal penulis menemukan beberapa indikasi masalah terkait pelaksanaan program sertifikasi guru, hal tersebut gambarkan sebagai berikut: 1) Kantor Kementerian Agama Kabupaten Bandung tidak melakukan penataan ulang terhadap sumber daya manusia yang ada di Kantor Kementerian Agama Kabupaten Bandung untuk mendukung berjalannya implementasi program secara efektif; 2) Masih terdapat ketidakpahaman para sasaran program akan proses pelaksanaan program sertifikasi guru dalam jabatan. Kurangnya sosialisasi yang diberikan oleh para pelaksana program kepada sasaran program yaitu para guru mengenai prosedur program sertifikasi guru mengakibatkan terhambatnya proses pelaksanaan dikarenakan banyak guru yang tidak memahami persyaratan yang dibutuhkan untuk sertifikasi; 3) Para pelaksana program sertifikasi guru ini tidak menjalankan apa yang telah ditetapkan dalam Standard Operational Procedure (SOP) program sertifikasi guru dalam jabatan, yaitu mengenai kegiatan monitoring, evaluasi, dan laporan.

Berdasarkan pemaparan masalah diatas, maka penulis tertarik melakukan sebuah penelitian mengenai "Implementasi Program Sertifikasi Guru Dalam Jabatan (Studi Pada Madrasah Aliyah Negeri Ciparay Kabupaten Bandung)".

\section{METODE}

Guna memahami bagaimana implementasi program sertifikasi guru oleh Kantor Kementerian Agama Kabupaten Bandung maka Penulis menggunakan metode penelitian kualitatif sebagai metodenya. Penulis menganggap bahwa metode penelitian kualitatif relevan sebagai dasar metode dalam penelitian ini, Penulis menganggap bahwa metode penelitian kualitatif relevan 
sebagai dasar metode dalam penelitian ini, karena fenomena yang terjadi tidak memungkinkan diukur secara tepat, sehingga guna mendapatkan pemahaman yang tepat diperlukan eksplorasi kepada para partisipan. Melalui metode penelitian kualitatif ini, penulis dapat mengkaji perspektif partisipan yang memiliki otoritas, data, informasi, maupun penjelasan mengenai pelaksanaan program sertifikasi guru dalam jabatan. Adapun dalam mengembangkan dan menggambarkan penelitian, Penulis menggunakan pendekatan penelitian deskriptif. Data diperoleh dengan menggunakan studi kepustakaan dan studi lapangan berupa observasi non-partisipan, wawancara mendalam, dan dokumentasi. Teknik triangulasi sumber dijadikan sebagai pemeriksaan keabsahan data dalam penelitian ini, kemudian data-data tersebut direduksi, disajikan, dan ditarik simpulan.

\section{HASIL DAN PEMBAHASAN}

Hasil penelitian yang penulis lakukan menunjukan bahwa: 1) Dalam aspek organisasi, hubungan kerja antar pelaksana program sertifikasi guru dalam jabatan untuk guru madrasah di Kabupaten Bandung sudah baik. Bentuk kerja sama antar instansi maupun lembaga dan alur komunikasi antara LPTK, Kantor Kementerian Agama Kabupaten Bandung, dan kepala sekolah Madrasah Aliyah Negeri Ciparay sebagai penyampai informasi kepada guru yang berperan sebagai sasaran program (peserta sertifikasi) dilakukan dengan cara sosialisasi dan koordinasi mengenai pelaksanaan program sertifikasi guru.

Selanjutnya untuk ketersediaan sumber daya. Sumber daya merupakan aspek penting dalam pelaksanaan suatu program, hal ini karena keberadaan sumber daya dapat mempengaruhi keberhasilan suatu program. Agar dapat dilaksanakan dengan baik, kesiapan sumberdaya pelaksana program adalah hal penting untuk diperhatikan. Sumber daya yang diperlukan dalam menjalankan suatu program terdiri dari beberapa macam yaitu: sumber daya manusia, sumber daya finansial, dan sumber daya sarana dan prasarana. dalam hal kuantitas sumber daya manusia untuk pelaksanaan program sertifikasi guru madrasah di Kabupaten Bandung masih kurang untuk beberapa kegiatan khususnya untuk perekapan data dan juga proses pengawasan yang meliputi kegiatan monitoring, evaluasi dan pembuatan laporan. Sedangkan kualitas sumber daya manusia untuk kompetensi dalam melaksanakan program dari pemberian wewenang dan tanggungjawab sudah cukup baik dilihat dari kegiatan program yang sampai saat ini masih terlaksanakan. Jika dilihat dari segi sumber daya anggaran untuk pelaksanaan program sertifikasi guru dalam jabatan untuk guru madrasah masih kurang dan hal ini menjadi kendala dalam implementasi program sertifikasi guru dalam jabatan pada guru madrasah di Kabupaten Bandung. Dan yang terakhir dilihat dari segi sumber daya sarana dan prasarana, berdasarkan hasil observasi peneliti melihat kurangnya sarana untuk kegiatan verifikasi dan pemberkasan meskipun para implementor mengatakan sudah memenuhi tapi melihat kondisi dilapangan tidak adanya ruang arsip untuk berkas, tidak adanya laptop yang disediakan dimana para implementor masih harus menggunakan barang pribadinya untuk mendukung pelaksanaan program sertifikasi guru dalam jabatan untuk guru Madrasah di Kabupaten Bandung ini.

Dalam melaksanakan program, sebagai pedoman dan panduan bagi pelaksana program maka perlu adanya aturan hukum dan Standard Operating Procedure (SOP) yang harus dipatuhi oleh semua pihak yang terlibat dalam pelaksanaan program tersebut. Dengan adanya panduan yang memuat tata cara dan mekanisme dalam pelaksanaan kegiatan dari pada program, dan jika hal 
tersebut dilaksanakan sesuai aturannya maka tujuan yang telah di tetapkan bisa tercapai. Implementasi program memerlukan perintah atasan yang jelas dan tegas, dan perlu memberikan sanksi bagi aparat yang melanggar, sebagaimana yang dikemukakan oleh Jones bahwa pemimpin diperlukan untuk memberikan perintah danmempertanggungjawabkan kewajiban-kewajiban tersebut dan kemudian dibagikan dalam cara yang tetap serta dibatasi secara ketat oleh aturan-aturan yang berhubungan dengan cara-cara paksaan dan sejenisnya, yang akan dikenakan sanksi berupa pemecatan atau pembuangan bagi para pejabat yang melakukannya.

2) Aspek Interpretasi, yang dimaksudkan oleh Jones dalam implementasi program adalah menafsirkan agar program menjadi rencana dan pengarahan yang tepat dan dapat diterima serta dilaksanakan. Bagaimana suatu program dapat dilaksanakan juga tergantung pada pemahaman dari para pelaksana atau implementor dalam mengartikan hal-hal yang berhubungan dengan satu kegiatan atau program, baik mengartikan maksud dan tujuan dari program tersebut. Kurangnya pemahaman para peserta yaitu guru dalam proses pelaksanaan program sertifikasi guru ini menimbulkan banyak kendala saat pelaksanaan itu berlangsung. Kenyataan ini menunjukkan bahwa guru yang sudah membaca buku pedoman sertifikasi guru saja belum sepenuhnya memahami isinya meskipun mereka akan mengikuti sertifikasi itu sendiri. Permasalahan seperti sebenarnya dapat diatasi dengan adanya komunikasi interaktif antara guru dan pelaksana yang memahami program sertifikasi guru dengan baik. Dan aspek yang terakhir adalah 3) Aspek Aplikasi, para pelaksana program diarahkan untuk melaksanakan program sesuai dengan pedoman dan aturan yang sudah ditetapkan, tapi pada kenyataan nya masih saja ditemukan adanya pedoman pelaksanaan program yang tidak di laksanakan. Akitivitas aplikasi merupakan tahap akhir dalam tahapan implementasi program, dimana penerapan merupakan ketentuan rutin dari pelayanan, pembayaran, atau lainnya yang disesuaikan dengan tujuan atau perlengkapan program. Penerapan untuk program sertifikasi guru dalam jabatan dapat melalui: a) Penyelenggaraan Program Sertifikasi Guru; b) Sosialisasi Program Sertifikasi Guru; c) Ketercapaian Tujuan dan Manfaat Program Sertifikasi Guru; dan d) Pemantauan, Evaluasi dan Pelaporan.

\section{SIMPULAN DAN SARAN}

Berdasarkan hasil penelitian yang telah dilaksanakan oleh peneliti mengenai Implementasi Program Sertifikasi Guru Dalam Jabatan (Studi Pada Madrasah Aliyah Negeri Ciparay Kabupaten Bandung), peneliti memperoleh kesimpulan bahwa pelaksanaan program sertifikasi guru pada guru madrasah yang dilakukan oleh Kementerian Agama Kabupate Bandung belum berjalan secara optimal. Hal tersebut dikarenakan pelaksanaan program sertifikasi guru masih belum memenuhi beberapa aspek implementasi program yang dikemukakan oleh Charles O. Jones yaitu organisasi, interpretasi, dan aplikasi yang belum berjalan sebagaimana mestinya dimana masih terdapat beberapa permasalahan dan hambatan.

1. Aspek organisasi, pada aspek ini masih ditemukan beberapa kendala dan permasalahan yang terjadi seperti kurangnya sumber daya, baik dari sdm, finansial, maupun sarana dan prasarana. Selain itu komunikasi yang terjalin dalam hubungan kerja antar pelaksana penyelenggara program sertifikasi guru dalam jabatan untuk guru madrasah di Kabupaten Bandung dalam hal komunikasi atau penyampaian pesan masih belum optimal kepada sasaran program serta masih kurang jelas. 
2. Pada aspek interpretasi, penulis menemukan bahwa pemahaman dari para pelaksana program sertifikasi guru dalam jabatan untuk guru Madrasah di Kabupaten Bandung terhadap program sertifikasi guru dalam jabatan sudah cukup memahami akan tujuan dan panduan program. Akan tetapi para pelaksana belum konsisten dalam menjalankan tugas dan fungsinya. Hal tersebut dikarenakan belum semua panduan yang telah ditetapkan berjalan sesuai yang diharapkan seperti belum optimalnya dalam melakukan sosialisasi sehingga pelaksanaan program sertifikasi guru dalam jabatan sehingga berpengaruh kepada pemahaman dari para peserta atau sasaran program (target group) pemahaman dari sasaran program juga turut menjadi kunci pelaksanaan program tidak mencapai tujuan.

3. Pada aspek aplikasi, dalam pelaksanaannya program sertifikasi guru dalam jabatan ini sudah berpedoman pada panduan yang ada. Akan tetapi tidak berjalan sesuai dengan panduan seperti sosialisasi. Selain itu, dalam hal pengawasan, evaluasi, dan pembuatan laporan juga masih belum dilaksanakan.

Berdasarkan simpulan yang telah dipaparkan sebelumnya, penulis mencoba memberikan beberapa saran yang mungkin dapat menjadi masukan bagi semua pihak yang tergabung dalam pelaksanaan program sertifikasi guru dalam jabatan untukguru madrasah di Kabupaten Bandung. Adapun saran-saran yang akan penulis kemukakan antara lain sebagai berikut:

1. Pentingnya peran petugas dalam pelaksanaan program sertifikasi guru dalam jabatan untuk guru madrasah di Kabupaten Bandung seharusnya diimbangi dengan pemenuhan jumlah sumber dayanya. Maka dari itu perlu untuk memerhatikan jumlah staf atau pegawai yang dibutuhkan untu melaksanakan segala kegiatan yang berhubungan dengan implementasi program sertifikasi guru serta sumber daya finansialnya.

2. Sosialisasi merupakan hal yang penting agar program sertifikasi guru dalam jabatan dapat berjalan sesuai dengan tujuan dan harapan. Maka dari itu seharusnya kegiatan sosialisasi ini lebih ditingkatkan lagi agar pelaksanaan program sertifikasi guru ini berjalan sesuai dengan panduan yang telah ditetapkan sehingga baik para pelaksana maupun peserta dapat melaksanakan tugas dan fungsinya masing-masing dengan baik.

3. Dalam melaksanakan suatu program, kegiatan pengawasan dan pembuatan lapon sangat dibutuhkan untuk nantinya dapat digunakan sebagai patokan atau acuan dan sebagai bahan evaluasi. Untuk itu seharusnya dalam memberikan laporan pelaksanaan program harus sesuai dengan jadwal yang telah ditentukan agar dapat melihat perkembangan dari program sehingga memudahkan dalam pengambilan keputusan dan tindakan selanjutnya.

\section{UCAPAN TERIMAKASIH}

Penulis menyadari bahwa tanpa bantuan serta bimbingan dari berbagai pihak, mulai dari awal hingga akhir penyusunan Skripsi ini, akan dirasa sangat sulit bagi Penulis untuk menyelesaikannya. Oleh karena itu, Penulis memberikan penghormatan yang setinggi-tingginya dan ucapan terima kasih yang sebesar-besarnya kepada pihak-pihak yang telah berkenan membantu Penulis dalam menyelesaikan penyusunan Skripsi ini.

\section{DAFTAR PUSTAKA}

\section{Buku}

Creswell,W. Jhon. 2010. Research Design: Pendekatan Kualitatif, Kuantitatif, dan Mixed. Yogyakarta: Pustaka Pelajar 
Dunn, William N. 2000. Analisis Kebijakan Publik. Yogyakarta: Gadjahmada University Press

Jones. Charles O. 1994. Pengantar Kebijakan Publik (Public Policy). Jakarta Utara: PT. Raja Grafindo Persada

Miles, Mathew B. And A. Michael Huberman. 1994. Qualitative Data Analysis. California: SAGE Publications

Moleong, Lexy J. 2007. Metode Penelitian Kualitatif. Bandung: Rosda

Mulyasa. E. 2009. Implementasi Kurikulum Tingkat Satuan Pendidikan.

Kemandirian Guru dan Kepala Sekolah. Jakarta: PT Bumi Aksara.

Muslich. Masnur. 2007. Sertifikasi Guru Menuju Profesionalisme Pendidik. Jakarta: PT Bumi Aksara.

Nugroho. Riant. 2011. Public Policy. Jakarta: PT. Elex Media Komputindo

Robbins, Stephen P., \& Judge, Timothy A. (2008). Perilaku Organisasi. (Ed. 12). (Diana Angelica, Penerjemah). Jakarta: Penerbit Salemba Empat.

Sarimaya. Farida.2008. Sertifikasi Guru (Apa. Mengapa. dan Bagaimana). Bandung: Yrama Widya

Subarsono. AG. 2005. Analisis Kebijakan Publik Teori. Konsep dan Aplikasi. Yogyakarta: Pustaka Pelajar

Sudarmanto. 2009. Kinerja dan Pengembangan Kompetensi SDM
(Teori. Dimensi Pengukuran. dan Implementasi dalam Organisasi. Yogyakarta: Pustaka Pelajar

Sugiyono. 1999. Metode Penelitian Sosial. Bandung: CV Alfabeta

Sugiyono. 2007. Metode Penelitian Kuantitatif. kualitatif. dan $R \& D$. Bandung: Alfabeta.

Tachjan, Dr. H, M.Si.2006. Implementasi Kebijakan Publik. Bandung: AIPI

Wahab. Solichin Abdul. 2004. Analisis Kebijakan dari Formulasi ke Implementasi Kebijaksanaan Negara. Jakarta: Bumi Aksara

Wibawa, Samudra, dkk.1994. Evaluasi Kebijakan Publik. Jakarta: Raja Grafindo Persada

\section{Dokumen-dokumen}

Buku 1 Pedoman Sertifikasi Guru Dalam Jabatan Tahun 2016

Undang-undang RI No. 20 Tahun 2003 Tentang Sistem Pendidikan Nasional

Undang-undang RI No.14 Tahun 2005 Tentang Guru dan Dosen

Peraturan Pemerintah Nomor 19 Tahun 2005. Tentang Standar Nasional

Peraturan Pemerintah Nomor 74 Tahun 2008. Tentang Guru

Peraturan Menteri Pendidikan Nasional Nomor 16 Tahun 2007 tentang Standar Kualifikasi dan Kompetensi Guru

Peraturan Menteri Pendidikan Nasional Nomor 11 tahun 2011 tentang Sertifikasi bagi Guru dalam jabatan

Peraturan Menteri Pendidikan Dan Kebudayaan Nomor 62 Tahun 2013 
Tentang Sertifikasi Guru Dalam

Jabatan Dalam Rangka Penataan

Dan Pemerataan Guru

Petunjuk Teknis Pelaksanaan Sertifikasi

Bagi Guru Raudlatul Athfal Dan

Madrasah Dalam Jabatan Tahun

2015

\section{Hasil Penelitian}

Alzano. Alfi. 2015. Efektivitas Program

Sertifikasi Guru Dalam

Meningkatkan Mutu Hasil

Pendidikan (Studi pada SMK Negeri

2 Batusangkar). Skripsi Program

Studi Administrasi

Publik.Bandung.Program Sarjana

Unpad

Nurhafni. 2010. Implementasi Program

Sertifikasi Guru Dalam Peningkatan

Mutu Pendidikan (Studi Kasus di

Kabupaten Aceh Utara.Jurnal JKAP

Volume 15 No 1

Nurhayati. Mira. 2008. Pengaruh

Implementasi Kebijakan Sertifikasi

Guru Terhadap Kinerja Guru SD

Negeri di Kecamatan Antapani pada

Dinas Pendidikan Kota Bandung.

Skripsi Program Studi Ilmu

Administrasi Negara. Surakarta.

Program Sarjana Universitas Sebelas

Maret 